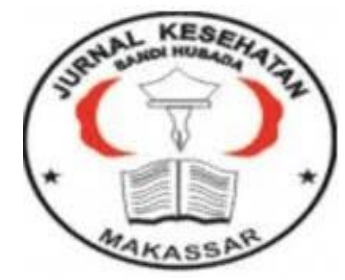

Jurnal Ilmiah Kesehatan Sandi Husada

hhttps://akper-sandikarsa.e-journal.id/JIKSH

Volume 9, Nomor 2, Desember 2020, pp 708-712

p-ISSN: 2354-6093 dan e-ISSN: 2654-4563

DOI: $10.35816 /$ jiskh.v10i2.385

\title{
Pengaruh Radiasi Gelombang Elektromagnetik Telepon Genggam Terhadap Perkembangan Sperma
}

Effect of Cellphone Electromagnetic Wave Radiation on the Development of Sperm

Asep Wahyudi Sudirman

Fakultas Kedokteran, Universitas Lampung

\section{Artikel info}

Artikel history:

Received; Juli 2020

Revised: Agustus 2020

Accepted; Agustus 2020

\begin{abstract}
Abstrak
Latar Belakang: Peningkatan penggunaan telepon genggam membuat para pengguna harus lebih mencermati efek samping penggunaan telepon genggam terhadap kesehatan manusia. kaum pria yang membawa telepon genggam di saku celana dapat menurunkan $70 \%$ produktivitas sperma dan lebih parah lagi sperma yang dihasilkan tidak akan dapat membuahi sama sekali alias mandul karena telah rusak akibat radiasi gelombang elektromagnetik yang dipancarkan oleh telepon genggam. Tujuan: mengetahui pengaruh radiasi gelombang elektromagnetik telepon genggam terhadap perkembangan sperma Metode: Menggunakan studi literatur dari jurnal baik nasional maupun internasional dengan cara meringkas topik pembahasan dan membandingkan hasil yang disajikan dalam setiap artikel. Hasil:Paparan gelombang elektromagnetik handphone dapat menyebabkan peningkatan produksi Reactive Oxygen Species (ROS) seperti Malondialdehyde (MDA) dan penurunan aktivitas antioksidan seperti katalase, Superoxide Dismutase (SOD) dan Gluthatione Peroxidase (GSH). Jumlah ROS yang melebihi antioksidan protektif dalam tubuh dapat menyebabkan stres oksidatif, kerusakan sel, dan jaringan. Stres oksidatif dapat meningkatkan peroksidasi lipid asam lemak tak jenuh pada membran sel spermatozoa. Degenerasi tubulus seminiferus juga dapat terjadi akibat ROS akan meningkat dapat menyebabkan penurunan motilitas spermatozoa, disfungsi sel Leydig dan sel Sertoli. Kesimpulan: penggunaan telepon genggam terbukti memberikan efek negative pada sistem reproduksi pria.
\end{abstract}

Abstract.

Background: Increased use of mobile phones has made users have to pay more attention to the side effects of cell phone use on human health. men who carry a cell phone in a pants pocket can reduce sperm productivity by $70 \%$ and even worse the sperm produced will not be able, to fertilize until infertile 
because it has been damaged by the electromagnetic wave radiation emitted by a cell phone. Objective: to determine the effect of cell phone electromagnetic radiation radiation on sperm development Method: Using literature studies from both national and international journals by summarizing the topic of discussion and comparing the results presented in each article. Results: Exposure to mobile electromagnetic waves can cause increased production of Reactive Oxygen Species (ROS) such as Malondialdehyde (MDA) and decreased antioxidant activity such as catalase, Superoxide Dismutase (SOD) and Gluthatione Peroxidase (GSH). The amount of ROS that exceeds protective antioxidants in the body can cause oxidative stress, cell damage, and tissue. Oxidative stress can increase lipid peroxidation of unsaturated fatty acids in spermatozoa cell membranes. Seminiferous tubular degeneration can also occur due to increased ROS which can cause decreased spermatozoa motility, dysfunction of Leydig cells and Sertoli cells. Conclusion: cell phone use has been proven to have a negative effect on the male reproductive system.

\author{
Keywords: \\ Telepon genggam; \\ gelombang \\ elektromagnetik; \\ Sperma;
}

Coresponden author:

Email: sepawahyudi17@gmail.com

artikel dengan akses terbuka dibawah lisensi CC BY 4.0

\section{Pendahuluan}

Setiap tahun angka pengguna telepon genggam di Indonesia semakin meningkat. Penelitian yang dilakukan Roy Morgan Research di Australia mengatakan bahwa pada tahun 2011, diperkirakan 65\% penduduk Indonesia telah memiliki ponsel, kemudian pada tahun 2012 menjadi 74\%, dan pada tahun 2013 meningkat menjadi 84\% dari jumlah populasi penduduk Indonesia (Guharoy, 2013). Peningkatan penggunaan telepon genggam membuat para pengguna harus lebih mencermati efek samping penggunaan telepon genggam terhadap kesehatan manusia (Ratna, 2011). Secara umum setiap bentuk radiasi gelombang elektromagnetik dapat berpengaruh terhadap tubuh manusia. Sel-sel tubuh yang mudah membelah adalah bagian yang paling mudah dipengaruhi oleh radiasi. Selain itu tubuh yang sebagian besar berupa molekul air, juga mudah mengalami ionisasi oleh radiasi. Mekanisme interaksi medan listrik dan magnetik dengan benda hidup sebenarnya sangat sederhana, yaitu berupa induksi medan dan juga arus listrik pada jaringan biologi. Potensi gangguan kesehatan yang timbul akibat pajanan medan elektromagnetik dapat terjadi pada berbagai sistem tubuh, antara lain, sistem darah, sistem reproduksi, sistem saraf, sistem kardiovaskular, sistem endokrin, psikologis, dan hipersensitivitas (Sylvia dkk, 2007).

Ponsel genggam mempunyai dampak yang akan mengganggu kesehatan mulai dari penyakit ringan seperti vertigo hingga penyakit berbahaya seperti kanker dan dapat menyebabkan infertilitas (Enny, 2014). Erogul pada tahun 2006 menyebutkan bahwa kualitas sperma dapat menurun akibat kebiasaan meletakkan handphone berdekatan dengan testis. Radiasi gelombang elektromagnetik handphone dapat menyebabkan terjadinya peningkatan stres oksidatif. Adanya stres oksidatif akan mempengaruhi 
struktur membran plasma sel sperma, merusak struktur Deoxyribonucleic Acid (DNA), dan mempercepat proses apoptosis yang pada akhirnya dapat mengakibatkan penurunan kualitas sperma (Erugol, 2006).

Penelitian di Amerika membuktikan bahwa kaum pria yang membawa telepon genggam di saku celana dapat menurunkan $70 \%$ produktivitas sperma dan lebih parah lagi sperma yang dihasilkan tidak akan dapat membuahi sama sekali alias mandul karena telah rusak akibat radiasi yang dipancarkan oleh telepon genggam yang ditaruh di saku celana. Pengamatan menunjukkan bahwa setelah pemajanan gelombang telepon seluler, diameter tubulus seminiferi dan jumlah sel-sel spermatogenik mengalami penurunan. Penurunan ukuran diameter tubulus seminiferi dan jumlah sel-sel spermatogenik merupakan indikator bahwa proses spermatogenesis berlangsung tidak normal. Hasil pengukuran diameter tubulus seminiferi pada penelitian ini menunjukkan bahwa penurunan ukuran diameter tubulus seminiferi yang bermakna pada mencit (Mus musculus) yang dipaparkan radiasi elektromagnetik dari telepon seluler jenis GSM monophonic, telepon seluler jenis GSM polyphonic, dan telepon seluler jenis CDMA dengan paparan kurang lebih 120 menit perhari selama 30 hari (Adie dan Nurul, 2008). Selain diameter tubulus seminiferi dan jumlah sel-sel spermatogenik mengalami penurunan, radiasi gelombang elektromagnetik dari telepon genggam juga dapat berefek menurunkan kecepatan gerak spermatozoa (Sylvia. dkk, 2007). Berdasarkan permasalahan tersebut, peneliti bermaksud melakukan tinjauan literatur yang bertujuan untuk mengetahui pengaruh radiasi gelombang elektromagnetik telepon genggam terhadap perkembangan sperma

\section{Metode}

Metode yang digunakan oleh penulis adalah studi literatur dari berbagai jurnal nasional maupun internasional. Studi literatur ini dilakukan dengan cara membaca, memahami, dan mereview literatur dari berbagai macam sumber. Metode ini digunakan dengan tujuan menyajikan, menambah pengetahuan dan pemahaman mengenai topik yang dibahas dengan meringkas materi yang telah diterbitkan serta memberikan informasi fakta atau analisis baru dari tinjauan literatur yang relevan kemudian membandingkan hasil tersebut dalam artikel.

\section{Hasil Dan Pembahasan}

Telepon genggam atau handphone merupakan sumber radiasi gelombang elektromagnetik yang sangat potensial, handphone menghasilkan energi foton yang sangat besar dan radiasinya lebih besar dibandingkan dengan peralatan elektronik maupun jaringan listrik yang bertegangan tinggi (Siti, 2016). Gelombang elektromagnetik adalah gelombang yang terbentuk dari interaksi antara medan magnetik dan medan listrik. Kedua medan ini bergetar dalam arah yang saling tegak lurus. Medan magnetik dan medan listrik pembentuk gelombang elektromagnetik adalah gelombang transversal, yang arah rambatnya tegak lurus dengan arah getarnya (USA GAO, 2008).

Secara umum setiap bentuk radiasi gelombang elektromagnetik dapat berpengaruh pada tubuh manusia. Sel-sel tubuh yang mulai membelah adalah bagian yang paling mudah dipengaruhi oleh radiasi. Tubuh yang sebagian besar berupa molekul air, juga mudah mengalami ionisasi oleh radiasi. Sehingga radiasi gelombang elektromagnetik sangat berpengaruh terhadap tubuh manusia (Anies, 2006).

Proses yang mengakibatkan gelombang elektromagnetik berpengaruh terhadap kesehatan adalah adanya perubahan keseimbangan kadar radikal bebas dalam sistem biologik. Radikal bebas adalah kemungkinan yang paling besar karena radikal bebas sangat reaktif dan mutagenik dalam sel hidup (Crumpton, 2005). Ponsel genggam mempunyai dampak 
yang akan mengganggu kesehatan mulai dari penyakit ringan seperti vertigo hingga penyakit berbahaya seperti kanker dan dapat menyebabkan infertilitas (Enny, 2014). Infertilitas adalah keadaan yang ditandai dengan tidak terjadinya kehamilan pada pasangan individu yang secara aktif melakukan hubungan seksual secara teratur tanpa menggunakan pengaman selama satu tahun (Roupa, 2009).

Paparan gelombang elektromagnetik handphone dapat menyebabkan peningkatan produksi Reactive Oxygen Species (ROS) seperti Malondialdehyde (MDA) dan penurunan aktivitas antioksidan seperti katalase, Superoxide Dismutase (SOD) dan Gluthatione Peroxidase (GSH). Jumlah ROS yang melebihi antioksidan protektif dalam tubuh dapat menyebabkan stres oksidatif, kerusakan sel, dan jaringan. Stres oksidatif dapat meningkatkan peroksidasi lipid asam lemak tak jenuh pada membran sel spermatozoa. Degenerasi tubulus seminiferus juga dapat terjadi akibat ROS. Peroksidasi dapat merusak integritas membran dengan meningkatkan permeabilitas membran. Salah satu teori menyatakan bahwa permeabilitas membran yang meningkat dapat menyebabkan penurunan motilitas spermatozoa, disfungsi sel Leydig dan sel Sertoli (Jedrzejowska, 2012).

Salah satu penelitian yang dilakukan oleh Salama, dkk pada tahun 2010 menyatakan bahwa stres oksidatif dapat dihasilkan oleh radiasi gelombang elektromagnetik ponsel. Paparan ponsel $800 \mathrm{MHz}$ dalam keadaan menyala selama 8 jam setiap hari selama 12 minggu yang dilakukan pada kelinci menunjukkan penurunan signifikan terhadap diameter tubulus seminiferus pada minggu-12 secara histologis. Almasiova juga melakukan pemaparan gelombang elektromagnetik selama 3 jam dalam waktu 3 minggu terhadap tikus putih dan menghasilkan gambaran degenerasi pada tubulus seminiferus dengan bentuk yang ireguler serta memiliki banyak ruang kosong akibat sel yang mengalami peluruhan (Salama, 2010). Hasil penelitian yang dilakukan oleh Wulan, dkk (2015) menunjukkan bahwa paparan gelombang elektromagnetik handphone selama 1 dan 3 jam mampu menurunkan motilitas spermatozoa secara bermakna namun tidak mampu menyebabkan penurunan jumlah spermatozoa secara bermakna. Penelitian Davoudi (2002) yang menilai parameter sperma manusia yang menggunakan handphone dengan durasi 6 jam selama 5 hari yang menghasilkan penurunan kualitas pada sperma tersebut, terutama motilitas spermatozoa. Durasi paparan per hari terbukti memberikan efek negatif pada spermatozoa mulai dari motilitas, jumlah, viabilitas, dan morfologinya. Sehingga diperkirakan apabila peneliti menggunakan durasi waktu paparan yang lebih lama, tidak hanya akan menghasilkan penurunan rerata jumlah spermatozoa, tetapi juga akan bermakna secara statistik. Berdasarkan hasil tinjauan literatur yang telah dilakukan, penggunaan telepon genggam terbukti memberikan efek negatif pada sistem reproduksi pria

\section{Simpulan Dan Saran}

Paparan gelombang elektromagnetik handphone dapat menyebabkan peningkatan produksi Reactive Oxygen Species (ROS) seperti Malondialdehyde (MDA) dan penurunan aktivitas antioksidan seperti katalase, Superoxide Dismutase (SOD) dan Gluthatione Peroxidase (GSH). Stres oksidatif dapat meningkatkan peroksidasi lipid asam lemak tak jenuh pada membran sel spermatozoa. Degenerasi tubulus seminiferus juga dapat terjadi akibat ROS akan meningkat dapat menyebabkan penurunan motilitas spermatozoa, disfungsi sel Leydig dan sel Sertoli. Penggunaan telepon genggam terbukti memberikan efek negative pada sistem reproduksi pria. 


\section{Daftar Rujukan}

Anggorowati, L. (2013). Faktor risiko kanker payudara wanita. KEMAS: Jurnal Kesehatan Masyarakat, 8(2).

DeSantis, C., Ma, J., Bryan, L., \& Jemal, A. (2014). Breast cancer statistics, 2013. CA: A Cancer Journal for Clinicians, 64(1), 52-62.

Dyanti, G. A. R., \& Suariyani, N. L. P. (2016). Faktor-Faktor Keterlambatan Penderita Kanker Payudara dalam Melakukan Pemeriksaan Awal ke Pelayanan Kesehatan. KEMAS: Jurnal Kesehatan Masyarakat, 11(2), 276-284.

Eismann, J., Heng, Y. J., Fleischmann-Rose, K., Tobias, A. M., Phillips, J., Wulf, G. M., \& Kansal, K. J. (2019). Interdisciplinary management of transgender individuals at risk for breast cancer: case reports and review of the literature. Clinical Breast Cancer, 19(1), e12-e19.

Fadhilah, L. N. (2020). Leukosit dan Kadar Bilirubin Total pada Ikterus Obstruktif yang Disebabkan oleh Tumor Pankreas. Jurnal Ilmiah Kesehatan Sandi Husada, 11(1), 183-189.

Hanriko, R. (2019). Mesothelin Sebagai Biomarker Deteksi Dini Kanker Pankreas. Jurnal Ilmiah Kesehatan Sandi Husada, 10(2), 143-150.

Kuswandi, A., Kuswandi, N. H., Kasim, M., \& Wulandari, M. (2020). Karakteristik Histopatologi dan Stadium Klinis Kanker Nasofaring. Jurnal Ilmiah Kesehatan Sandi Husada, 11(1), 243-251.

Murphy, G. S., Szokol, J. W., Greenberg, S. B., Avram, M. J., Vender, J. S., Nisman, M., \& Vaughn, J. (2011). Preoperative Dexamethasone Enhances Quality of Recovery after Laparoscopic CholecystectomyEffect on In-hospital and Postdischarge Recovery Outcomes. Anesthesiology: The Journal of the American Society of Anesthesiologists, 114(4), 882-890.

Prasetyowati, P., \& Katharina, K. (2017). Faktor-Faktor Yang Berhubungan Dengan Kejadian Kanker Payudara Di RSUD Dr. H. Abdul Moeloek Provinsi Lampung. Jurnal Kesehatan Metro Sai Wawai, 7(1), 75-84.

Sari, N., \& Afni Amran, V. (2019). Hubungan Penggunaan Kontrasepsi Oral dengan Kanker Payudara Wanita Premenopause. Jurnal Ilmiah Kesehatan Sandi Husada, 10(2), 132-137.

Surbakti, E. (2013). Hubungan Riwayat Keturunan Dengan Terjadinya Kanker Payu-dara Pada Ibu Di RSUP H. Adam Malik Medan. Precure, 1, 160007.

Yusmaidi, Y., Rafie, R., Nur, M., \& Nabilah, B. (2020). Derajat Toksisitas Trombosit pada Penderita Kanker Kolorektal yang Mendapat Kemoterapi CapeOX. Jurnal Ilmiah Kesehatan Sandi Husada, 11(1), 313-320. 